KYIV-MOHYLA HUMANITIES JOURNAL

\title{
A Trial in Absentia: Purifying National Historical Narratives in Russia
}

Author(s): Olga Bertelsen

Source: Kyiv-Mohyla Humanities Journal 3 (2016): 57-87

Published by: National University of Kyiv-Mohyla Academy

http://kmhj.ukma.edu.ua/ 


\title{
A Trial in Absentia: Purifying National Historical Narratives in Russia ${ }^{1}$
}

\author{
Olga Bertelsen \\ Columbia University, \\ Harriman Institute
}

\begin{abstract}
This study explores contemporary Russian memory politics, and analyzes the ideological underpinnings of the 2011 Moscow court verdict that criminalized a Ukrainian scholarly publication, accusing it of inciting ethnic, racial, national, social, and religious hatred. This accusation is examined in the context of Russia's attempts to control the official historical narrative. Special attention is paid to the role of Russian cultural and democratic civic institutions, such as the Moscow library of Ukrainian literature and Memorial, in the microhistory of this publication. Deconstructing the judicial reaction of Russian lawmakers toward the Ukrainian publication, the study analyzes the Russian political elite's attitudes toward the "Ukrainian" historical interpretations of Stalin's terror and other aspects of common Soviet history, and demonstrates the interconnectedness of the preceding Soviet and modern Russian methods of control over education, history, and culture. Language and legislation play an important role in Russian memory politics that shape the popular historical imagination and camouflage the authoritarian methods of governing in Russia. The case of the Ukrainian publication is contextualized by examining the cult of chekism and the discursive significance of anti-Ukrainianism, salient elements in Russian memory politics that have transcended national borders.
\end{abstract}

Key Words: Russia, Ukraine, memory politics, extremism, ckekists, ideological subversion.

In 2011, under the supervision of the Investigative Committee of the Prosecutor's Office of the Russian Federation in Moscow, the Investigative Department of the Meshchanskii district court launched a criminal case against the authors of the scholarly publication ChK-GPU-NKVD $v$ Ukraini: Osoby. Fakty. Dokumenty (ChK-GPU-NKVD in Ukraine: People. Facts. Documents, hereafter ChK in Ukraine) Yurii Shapoval, Volodymyr Prystaiko, and Vadym Zolotariov. ${ }^{2}$

\footnotetext{
$1 \quad$ I am grateful to Bohdan Vitvitsky, Roman Procyk, Peter Solomon, and Dale A. Bertelsen for their attentive reading of earlier drafts of this manuscript and their thoughtful suggestions.

2 Yurii Shapoval, Volodymyr Prystaiko, Vadym Zolotariov, ChK-GPU-NKVD v Ukraini: Osoby, Fakty, Dokumenty [ChK-GPU-NKVD in Ukraine: Individuals, Facts, Documents] (Kyiv: Abris, 1997). ChK, GPU, and NKVD are acronyms for the Soviet secret police. Those who worked for the ChK and its successive organs are referred to as chekists.
} 
They were accused of allegedly inciting ethnic, racial, national, social and religious hatred, of violating human rights, and of conscious activities aimed at producing and distributing extremist materials in the territory of the Russian Federation, activities which constituted a crime pursuant to Article 282 (part 1) of the Russian Criminal Code. ${ }^{3}$ The criminal case was opened and a preliminary investigation began, but there is no evidence that the investigation was completed. However, the related civil case initiated by a Meshchanskii District prosecutor of the city of Moscow was concluded. The court decision was reached on December 1, 2011, identifying the publication as a typical example of extremist literature that undermines the friendship between two brotherly peoples, Ukrainian and Russian, and exacerbates national tensions between them. The court ordered its removal from libraries. The decision was supported by the findings of a special cultural and linguistic commission organized under the auspices of the Institute of Language Studies (the Russian Academy of Sciences).

ChK in Ukraine was published in 1997 by the National Academy of Sciences in collaboration with the Security Service of Ukraine. In Western, Russian, and Ukrainian scholarship, the publication remains a classic reference on the activity of the repressive Bolshevik institution, the Soviet secret police. ${ }^{4}$ Since 1997, Shapoval, Prystaiko, and Zolotariov had published numerous

3 "Ugolovnyi Kodeks RF s komentariiami. Komentarii k statie 282 [The Criminal Code of the Russian Federation with Comments. Comments to Article 282]," Ugolovnyi Kodeks RF, 1996, 2015 ed., accessed March 28, 2016, http://rfuk.ru/comment_282.html. Article 282 defines the crime and punishment for actions, carried out publicly or through the mass media, consciously aimed at inciting hatred or hostility, or at humiliating human dignity on the basis of sex, race, nationality, language, origin, religious affiliation, or social group membership. The spectrum of punishment ranges from noncustodial sanctions in less serious and first offenses to 5 years in prison in more serious offenses.

4 See, for instance, Lynne Viola, The NKVD on Trial in Ukraine (a manuscript on Ukrainian chekists, prepared for publication); Matthew D. Pauly, Breaking the Tongue: Language, Education, and Power in Soviet Ukraine, 1923-1934 (Toronto: University of Toronto Press, 2014), 397; Olga Bertelsen and Myroslav Shkandrij, "The Secret Police and the Campaign against Galicians in Soviet Ukraine, 192934," Nationalities Papers: The Journal of Nationalism and Ethnicity 42.1 (2014): 37-62; Serhii Bilokin, Masovyi teror yak zasib derzhavnoho upravlinnia v SRSR (1917-1941 rr.): Dzhereloznavche doslidzhennia [Mass Terror as a Tool of State Governance in the USSR, 1917-1941: A Study of Sources], vol. 2 (Drohobych: Kolo, 2013), 212; Myroslav Shkandrij and Olga Bertelsen, “The Soviet Regime's National Operations in Ukraine,1929-1934," Canadian Slavonic Papers LV.3-4 (2013): 417-47; Olga Bertelsen, "GPU Repressions of Zionists: Ukraine in the 1920s," Europe-Asia Studies 65.6 (2013): 1080-1111; Tamara Vronska, Upokorennia strakhom: Simeine zaruchnytstvo u karalnii praktytsi radianskoi vlady (1917-1953) [Subversion by Fear: Family Members as Hostages in Punitive Practice of Soviet Power, 1917-1953] (Kyiv: Tempora, 2013), 38; Myroslav Shkandrij, Jews in Ukrainian Literature: Representation and Identity (New Haven; London: Yale University Press, 2009), 251; Mykola Doroshko, Nomenklatura: Kerivna verkhivka radianskoi Ukrainy (1917-1938 rr.) [Nomenklatura: The Governing Leadership in Soviet Ukraine, 19171938] (Kyiv: Nika-Tsentr, 2008), 42; A. G. Tepliakov, "Mashina terrora: OGPU-NKVD Sibiri v 1929-1941 gg. [The Machine of Terror: OGPU-NKVD in Siberia, 1929-1941]," Memorial, 2008, accessed March 28, 2016, http://www.memorial.krsk.ru/Articles/20o8Teplyakov/oo.htm; Silvia Salvatici, ed., Confini. Costruzioni, attraversamenti, rappresentazioni (Soveria Mannelli, Catanzaro: Rubbettino, 2005); 
other articles and books examining the inner workings of the Soviet secret organs during the interwar period. Among other things, they attempted to recreate the socio-psychological portraits of chekists who worked in the Ukrainian ChK/GPU/NKVD, basing their work on various sources that included archival documents, oral histories, and official documents discovered in the Soviet press. The 1997 publication clarifies the interlocking relationships between the central secret organs and those of the individual Soviet republics as well as the role of the center in the repressions of the late 1920s, the early 1930s, and the Great Terror of 1936-1938 in Ukraine.

Interestingly enough, the narrative adopted by this book became ideologically problematic for the Russian political leadership only in 2011, when memory politics in Russia and the new nascent Russian identity began to gain clearer contours. But a number of initiatives designed to counterbalance national historical narratives that began to emerge in the former Soviet republics as a result of the archival revolution were launched almost a decade earlier. ${ }^{5}$

On July 25, 2002, under Vladimir Putin's presidency, a federal law entitled "About Countering Extremist Activities" was enacted. ${ }^{6}$ Broadly defined, this law enabled prosecutors on all levels within the Russian Federation to identify examples of extremist activities and to file direct complaints in court explaining the crimes allegedly committed. Specifically, Article 13 of this law stipulates that a court ruling is required which would provide the grounds for removal of extremist materials from the public sphere, and that the ruling must be sent to an executive level federal justice office responsible for compiling the list of extremist materials. Individuals who engage in illegal production, distribution, or storage of such materials bear administrative or criminal responsibility. From 2004 to May 5, 2016, 3,426 sources were criminalized under this law and characterized as extremist. They included books, journals, brochures, newspapers, articles, films, documentaries, video files, and even comments posted on Internet websites and blogs. ${ }^{7}$

Through the lens of one Ukrainian publication's history, this case study explores how a state-sponsored historical narrative in Russia has been reinforced by silencing competing

Timothy Snyder, Sketches from a Secret War: A Polish Artist's Mission to Liberate Soviet Ukraine (New Haven; London: Yale University Press, 2005), 284; Kate Brown, A Biography of No Place: From Ethnic Borderland to Soviet Heartland (Cambridge, MA: Harvard University Press), 2003, 276; Volodymyr Semystiaha, "The Role and Place of Secret Collaborators in the Informational Activity of the GPUNKVD in the 1920 s and 193 os (on the Basis of Materials of the Donbass Region)," Cahiers du Monde russe 42.2-4 (2001): 232; Vladimir Khaustov, Deiatelnost organov gosudarstvennoi bezopasnosti NKVD SSSR (1939-1941 gg.) [The Activities of State Security Organs, the NKVD of the USSR, 1939-1941] (Moscow: Chelovek i nauka, 1998), accessed March 28, 2016, http://cheloveknauka.com/deyatelnost-organovgosudarstvennoy-bezopasnosti-nkvd-sssr-1939-1941-gg.

$5 \quad$ For a discussion about the Russo-Ukrainian historiographic encounter, see Serhii Plokhy, Ukraine and Russia: Representations of the Past (Toronto: University of Toronto Press, 2008).

$6 \quad$ "Federalnyi zakon 'O protivodeistvii ekstremistskoi deiatelnosti' [The Federal Law “About Countering Extremist Activities"]," Sovet bezopasnosti Rossiiskoi Federatsii, 2002, accessed March 28, 2016, http:// www.scrf.gov.ru/documents/17/31.html.

7 "Federalnyi spisok ekstremistskikh materialov [The Federal List of Extremist Materials]," Ministerstvo Yustitsii Rossiiskoi Federatsii, 2004, accessed March 28, 2016, http://minjust.ru/ru/extremist-materials. 
national historical interpretations and the memory of Soviet dictatorship. It offers an analysis of the court proceedings of a "book trial" that appears to be strongly influenced by Soviet ideology, and Soviet practices and traditions established during the Stalin era. By reintroducing practices such as trials in absentia, Russia attempts to silence the voices of historians in neighboring independent states and to restore a common ideological and cultural space that once had been Soviet.

The case of the Ukrainian publication is contextualized by examining the cult of chekism and the discursive significance of anti-Ukrainianism, salient elements in Russian memory politics that had transcended national borders. This process began long before Russia's military invasion in Ukraine in 2014. ${ }^{8}$ Designed to destabilize the neighboring country and being an inseparable part of a chekist tactic of ideological subversion, these politics encroached upon individual and collective spaces of cultural and intellectual sovereignty in Ukraine.

The sections that follow will focus on factors that contributed to the Russian authorities' attitudes toward ChK in Ukraine, analyze the anatomy of the court proceedings and methods of identifying extremist literature that should be included in the Federal List of Extremist Materials, examine Memorial's role in this case study, and provide a brief overview of how the Russian leadership structures national memory.

\section{ChK in Ukraine as a Nuisance}

In order to better understand Moscow's attitude toward the authors' interpretation of Soviet dictatorship, a closer examination of the structure and main objectives of the book seems appropriate. ChK in Ukraine is divided into three sections. The first section includes individual histories of key players in mass terror and repressions during the interwar period in Ukraine. Among them are the leading chekists in Ukraine: Vsevolod Balytskyi, Yukhym Yevdokymov, Karl Karlson, and Izrail Leplevskyi. The second section contains a collection of archival documents and other primary sources that reveal the centrality of state control in Ukraine in the 193os. The collection also includes the texts of two important pieces of legislation issued in independent Ukraine - "About the Rehabilitation of Victims of Political Repressions in Ukraine" (April 17, 1991) and "About the Security Service of Ukraine" (March 25, 1992). ${ }^{9}$ The third section presents brief biographical data about the most prominent chekists in the Soviet secret police, specifically those whose activities were linked to Ukraine at various periods of their professional careers. In addition, this section includes never-before published photos of these chekists and photocopies of several important archival documents, along with an explanation of abbreviations broadly

8 Andrei Illarionov, "Putin Was Preparing War for 11 Years," Khartyia'97, 2014, accessed March 28, 2016, http://www.charter97.org/en/news/2014/11/21/127194/.

$9 \quad$ "About the Security Service of Ukraine [Sluzhba bezpeky Ukrainy, SBU]" became the first law in independent Ukraine that identified the functions of the SBU. In the Soviet Union, there was no law that would regulate the work of the secret organs. See Yurii Shapoval, "Rosiiske kerivnytstvo obralo ahresyvnu liniiu shchodo ukrainskykh orhanizatsii [The Russian Leadership Has Chosen an Aggressive Course in Regards to Ukrainian Organizations]," Tyzhden, 2012, accessed March 28, 2016, http://tyzhden.ua/Politics/57335. 
employed by the secret organs. All of these have been of great value to scholars who study the structure of the Soviet secret organs, their goals, and their modus operandi.

Shapoval, Prystaiko, and Zolotariov's scholarship analyzed the brutality of the secret police covert operations in Ukraine and proactively attempted to dethrone the cult of the ChK/ GPU/NKVD that has now been meticulously revived in Russia for more than a decade. Archival documents, many of which were published in ChK in Ukraine for the first time, provide an inconveniently detailed picture of the Kremlin's national operations in Ukraine, one of the most important, "large and distinctive" Soviet republics, using Stalin's definition, ${ }^{10}$ and essentially emasculate Russia's new heroic chekist mythology. ${ }^{11}$ Not surprisingly, texts like ChK in Ukraine have become problematic in Russia, and their public accessibility undermines the efforts of the FSB and the Russian political leadership to sanitize the reputation of the FSB's predecessor, the Soviet secret police, and to rationalize its use of terror. ${ }^{12}$

Crucially, the biographical approach employed by Shapoval, Prystaiko, and Zolotariov helped them analyze authentic voices of those who worked for the secret organs, and examine the moral criteria that guided Soviet chekists' behavior. It was from this perspective that the authors of ChK in Ukraine posit that corruption, amorality, and theft marked the entire history of the ChK-GPU-NKVD. ${ }^{13}$ This viewpoint and the evidence they provide to support it cast a dubious shadow on the secret organs. In addition, the authors have deconstructed the mechanisms of how the chekists functioned and how the Soviet political leadership viewed Soviet Ukraine. According to the authors, Ukraine was a key republic for sustaining the Soviet empire with its center in Moscow. On several occasions, Ukraine became a testing ground for Stalin's economic and political experiments that resulted in millions of human deaths. Moreover, the authors of ChK in Ukraine have emphasized that a pronounced anti-Ukrainian stance emerged as a central feature in the documents produced by the center in the late twenties. ${ }^{14}$ This argument and the documents that supported it, which were included in the book, are in drastic contrast to Russia's official historical narrative and to the rhetoric of current Russian leaders. Prior to the annexation of Crimea and the invasion of Eastern Ukraine, Ukrainians were "partners," "brothers," "good neighbors," and "good relatives" and, generally speaking, Ukrainians and Russians have always been "ethnically and historically close" peoples. ${ }^{15}$

$10 \quad$ R. W. Davies, Oleg V. Khlevniuk, and E. A. Rees, eds., The Stalin-Kaganovich Correspondence, 1931-36, trans. Steven Shabad (New Haven; London: Yale University Press, 2003), 180.

" Julie Fedor, Russia and the Cult of State Security (London; New York: Routledge, 2011).

${ }_{12}$ FSB is an acronym for the Federal Security Service of the Russian Federation [Federalnaia sluzhba bezopasnosti].

13 Shapoval, Prystaiko, and Zolotariov, ChK-GPU-NKVDv Ukraini, 15-16, 127, 137, 271-79.

${ }_{14}$ Shapoval, Prystaiko, and Zolotariov, ChK-GPU-NKVDv Ukraini, 43.

${ }_{15}$ Michael S. Gorham, After Newspeak: Language Culture and Politics in Russia from Gorbachev to Putin (Ithaca; London: Cornell University Press, 2014), 147; Katherine Jacobsen, "Stalin's Story Takes Positive Twist: Tale Turns as Russians Seek Unity," Press Enterprise, March 27, 2016, 23; see also the Russian translation of the Russian historian Yurii Afanasiev's interview by Frankfurter Rundschau "Populiarnost Stalina sredi rossiian osnovana na emotsiiakh i mifakh," NEWS.ru.com, 2003, accessed March 28, 2016, http://www.newsru.com/world/o5mar20o3/stalin3.html. During Viktor Yushchenko's 
In this context, there seem to be several reasons for odious accusations against the book persecuted by the Russian authorities. One of them is closely linked to Russia's attempts at revising the chekist history. Since 200o, Russian president Putin, who "openly took pride in his past as a 'chekist,"' has been patiently restoring old Soviet political police traditions, methods and values. ${ }^{16}$ In doing so, he has taken specific measures aimed at curtailing the stream of journalistic and scholarly publications that analyzed the role played by the secret organs in Soviet terror and repressions. The KGB and the Presidential archives that were briefly opened in Russia in the 199os have been again restricted by the state to prevent chekist history from being studied and analyzed.

The book's collection of archival documents about the chekists' crimes reveals a substantial gap between the democratized archival procedure in Ukraine and the restricted access to similar documents in Russian archives, which challenges Russia's declarations about its supposed transformation into a democratic state. Since 200o, dramatic changes have occurred in the area of information access. In 2001, for example, Putin issued a presidential decree establishing "The Interagency Commission to Defend State Secrets." As a result, previously de-classified archival documents were re-classified, and historians faced, as Olga Velikanova has noted, an "archival counter-revolution." ${ }^{17}$ Earlier, an American scholar described the situation pertaining to Moscow's archives in the following manner:

Thelong-expected restrictions in Russian archival policy havearrived. The Putin regime has had a powerful chilling effect on research access (especially among foreigners) to previouslyclassifiedmaterialsin Russianarchives. Evendocuments thathave beencited in publications, or read by researchers in earlier years, have over the past year been reclassified. According to archivists in Moscow, the MVD [Ministry of Internal Affairs] and FSB [Federal Security Service, the post-Soviet KGB] have sent agents to each archive and communicated the clear message that patterns of special access observed throughout the 199 os are now over. ${ }^{18}$

Indeed, the archival revolution proved to be short-lived in Russia. In Ukraine, however, historians continued to enjoy access to communist party and former KGB archives, recovering information that contributed to a better understanding of the methods and tactics of the secret

tenure as Ukraine's president, Putin was openly hostile to Ukraine. For more details, see Anders Aslund, Ukraine: What Went Wrong and How to Fix It (Washington, DC: Peterson Institute for International Economics, 2015), 77-78.

16 Julie Fedor, Russia and the Cult of State Security (London, New York: Routledge, 2011), 119.

${ }_{17}$ Olga Velikanova, "Soviet Archives and Dark Truths (Jamie Glazov's Interview)," FrontPage Magazine, 2009, accessed March 28, 2016, http://archive.frontpagemag.com/readArticle.aspx? ARTID=33973.

18 Jeffrey Burds, "Ethnicity, Memory, and Violence: Reflections on Special Problems in Soviet and East European Archives," in Archives, Documentation, and Institutions of Social Memory: Essays from the Sawyer Seminar, eds. Francis X. Blouin Jr. and William G. Rosenberg (Ann Arbor: University of Michigan Press, 2006), 474. 
organs. ${ }^{19}$ ChK in Ukraine opened a window into the world of professional research on this topic in Soviet history.

Such information continues to be deemed sensitive in Russia for a number of reasons. But one reason seems to more fully explicate the 2001 presidential decree mentioned earlier. It is not a secret that institutional structures and operational tactics within the law enforcement organs, including the FSB, remain largely unchanged. ${ }^{20}$ Therefore, any rhetorical and conceptual parallels between Soviet and contemporary chekists require a positive vector of public discourse to promote the unquestionable image of a chekist. The scholarship of the Ukrainian authors and the archival documents they published in this volume clearly compromised the "purity" of such discourse, and at the very least constitute extremism in the eyes of ex-KGB officials in Moscow. The book that had the potential to equip its readers with insights into the roots and nature of modern Russian politics and ideology was to be criminalized and placed on the Federal List of Extremist Materials.

In addition, to recast the disreputable past of the chekists, a past that gradually found its way into the pages of the press and scholarly literature after 1991, and to repair the prestige of the secret police damaged by "excessive" democracy, an ostentatious celebration of Chekist's Day became an annual affair. This is considered now a professional holiday of the Russian political elite, of whom many are former chekists. ${ }^{21}$ The event is widely publicized, and a number of Russian pop singers have participated in concerts arranged as a celebratory treat for the former and current associates of this powerful agency. The romanticization of the KGB (and its successor - the FSB) helped the agency reinvent itself as a defender of Russia's national interests, and allowed its members to join the state bureaucracy and business elites. ${ }^{22}$ Michelle Van Cleave, former head of U.S. counterintelligence, has further argued that ultimately the new FSB coopted government institutions:

in the past, the services worked for the Communist Party and the party ran the state... Now, the intelligence services are the state. That's a very different government structure than we're accustomed to. ${ }^{23}$

There is, however, another significant component of Shapoval, Prystaiko, and Zolotariov's study that prompted the court to charge the authors with "igniting hatred between brotherly

$19 \quad$ See footnote 3.

${ }_{20}$ Martin Ebon, KGB: Death and Rebirth (Westport; London: Praeger, 1994); Michael J. Waller, "Russia: Death and Resurrection of the KGB," Demokratizatsiia 12.3 (2004): 333-55.

${ }_{21}$ Fedor, Russia and the Cult of State Security, 131. For a discussion about the rejuvenation of the cult of the Soviet Union's secret police, which under a new name runs the Kremlin today, see Edward Lucas, The New Cold War: Putin's Russia and the Threat to the West (New York: Palgrave Macmillan, 2008).

${ }_{22}$ Andrei Soldatov and Irina Borogan, The New Nobility: The Restoration of Russia's Security State and the Enduring Legacy of the KGB (New York: Public Affairs, 2010), 27.

${ }^{23}$ Quoted in Michael J. Waller, "Putin Celebrates Birth of KGB, USSR's Hated Spy Service," Center for Security Policy, 2013, accessed March 28, 2016, http://www.centerforsecuritypolicy.org/2013/12/20/ putin-celebrates-birth-of-kgb-ussrs-hated-spy-service. 
states" (i.e., Ukraine and Russia). Among other things, ChK in Ukraine provides evidence of the national element in Stalin's repression, and especially in his terror by famine that culminated in the Holodomor of 1932-1933, which resulted in millions of deaths in Ukraine. ${ }^{24}$ The Kremlin's official position on the Ukrainian interpretation of Stalin's terror and the Holodomor are well documented. Russia's political elite reject the idea that Stalin singled out the Ukrainians for mass killings. In 2006 the Russian Duma passed a resolution denying the genocidal nature of the Holodomor, and in 2008 Russian President Dmitry Medvedev refused to attend the commemorative events dedicated to the seventy-fifth anniversary of the Holodomor. Those who investigated the national component of Stalin's repression in the past or those who insist on the genocidal thesis of the famine at present have been criminalized. It became equally dangerous for anyone to maintain this position in contemporary Russia, and this was the case in Yanukovych's Ukraine as well. ${ }^{25}$ Using modern Russian legal language, those supporting (or even mentioning) this theory of deliberate national targeting are seen as perpetrators of extremist activity.

Finally, the ideas expressed in the foreword written for ChK in Ukraine by Serhii Holovatyi, the Minister of Justice in Ukraine at the time the work was published, likely contributed to the Moscow court decision. Holovatyi emphasized that the 1991 democratic choice of Ukraine to become independent rather than to remain a Soviet republic "should become a guarantee that the lawlessness [would] never be repeated." A line of demarcation had been ultimately drawn between a "lawless Ukraine under Moscow," and a "free Ukraine" that countered the myth of the glorified Russian past. Holovatyi's call for repentance for the crimes of their predecessors, addressed to those who then worked in the security services, reinforced a connection between Soviet and contemporary chekists. ${ }^{26}$ For Moscow, this call alone went against the principles of the secret agency's solidarity and besmirched the very reputation of the state judicial organs.

\section{The Anatomy of the Court Proceedings}

The preliminary investigation of the crime Shapoval, Prystaiko, and Zolotariov allegedly committed before the Russian state was conducted through forensic linguistic examination that was implemented by a commission of three experts employed by the Institute of Language Studies (the Russian Academy of Sciences):27 Evgenii Tarasov (doctor filologicheskikh nauk),

${ }_{24}$ Shapoval, Prystaiko, and Zolotariov, ChK-GPU-NKVDv Ukraini, 50-59, 99-100, 104, 126, 226, 254-67, 286, 298-99.

${ }_{25}$ Alexander J. Motyl, "Deleting the Holodomor: Ukraine Unmakes Itself," World Affairs, 2010, accessed March 28, 2016, http://www.worldaffairsjournal.org/article/deleting-holodomor-ukraine-unmakesitself.

${ }_{26}$ Shapoval, Prystaiko, and Zolotarov, ChK-GPU-NKVDv Ukraini, 6.

${ }_{27} \quad$ Forensic linguistics is at the intersection of linguistics and the law, including law enforcement. See John Olsson, Forensic Linguistics: An Introduction to Language, Crime and the Law (London and New York: Continuum, 2004). Often this area of linguistics is referred to as juridical linguistics (iurislingvistika). See A. N. Baranov, Lingvisticheskaiia ekspertiza teksta: teoriia i praktika [Forensic Linguistics: Theory and Practice ], 4 ed. (Moscow: Flinta-Nauka, 2012), 10. 
whose scholarly interests include German linguistics, intercultural communication and psycholinguistics; Tatiana Kurokhtina (kandidat filologicheskikh nauk), whose thesis examined the interferential inter-linguistics in bilingual (Russian and Ukrainian) practices; and Ekaterina Oshchepkova (kandidat filologicheskikh nauk), whose area of expertise is psycho-linguistics and cultural analysis of linguistic systems. The objective of the commission was to establish whether the text contained statements calling for extremist activities or statements that justified such activities, tools that might be used by the authors to manipulate public consciousness. The techniques for this particular kind of forensic examination were designed by the Russian linguist Anatolii Baranov, and are broadly employed by linguists in preparing their conclusions. ${ }^{28}$

Unfortunately, the text of the commission's conclusions is unavailable for an analysis. However, the court decision (its text can be accessed at the official site of the Meshchanskii district court in Moscow) contains quotations from Tarasov, Kurokhtina, and Oshchepkova's conclusions. The commission claimed that ChK in Ukraine was a vehicle for inflaming conflict between the nations, - an insult that tarnished both the Russians, as heirs of Soviet culture, and the Ukrainians, as former contributors to Soviet culture. ${ }^{29}$ The examining scholars' professional interests, as well as the thematic and analytical focus of their own publications, raise some doubts about the veracity of their conclusion.

Indeed, an analysis of the scholarly and professional records of each member of this commission reveals that only Kurokhtina possessed sufficient knowledge to read and understand texts written in Ukrainian. Attempting to argue that a substantive and thorough analysis of the Ukrainian text could be expected of either Tarasov, or Oshchepkova, whose records provide no indication of Ukrainian language skills adequate to fulfill the court assignment, appears problematic. In Tarasov's case, despite the fact that he is an expert in intercultural communication and a senior scholar, his German linguistic skills would be of little help in completing the task posed by the Meshchanskii District Court. Oshchepkova's record reveals no information about her mastering any foreign language whatsoever. And Kurokhtina's lack of professional experience (she defended her master's thesis a year before the 2011 trial) falls far short of the professional credentials that might be expected in this situation. The inner workings of how this troika was appointed as members of this commission remain unknown.

No doubt, the members of the commission found themselves in a very difficult situation: they were required by law to cooperate with the authorities. ${ }^{30}$ Moreover, the prosecutor subjected them to a significant degree of pressure, providing them with a definition of the crime that was applied to the transgressors before the commission reached a conclusion. The

${ }_{28}$ Baranov, Lingvisticheskaiia ekspertiza teksta; S. I. Krassa, "Metody sudebnoi lingvisticheskoi ekspertizy: prakticheskaia tipologiia [The Methods of Juridical Linguistics: A Practical Typology]," paper delivered at the conference "SWorld: Modern Problems and Ways of their Solution in Science, Transport, Production and Education," December, 18-27, 2012.

${ }_{29}$ "Informatsiia po delam i sudebnym aktam [Information about Cases and Court Protocols]," Meshchanskii raionnyi sud goroda Moskvy, 2011, accessed March 28, 2016, http://meshansky.msk.sudrf. $\mathrm{ru} /$ modules.php?name=information\&rid $=45$.

3о $\quad$ For the procedural details of juridical linguistics, see John Olsson, "What is the Forensic Linguistics?" The Text, 2015, 11, accessed March 28, 2016, http://www.thetext.co.uk/docs/what_is.doc. 
essence of this crime is described in Article 282 (part 1) of the Criminal Code of the Russian Federation, information that made it into the text of the court decision. ${ }^{31}$ The prosecutor had demanded that the publication be identified as an example of "extremist" literature. ${ }^{32}$ The assistant prosecutor N. A. Gashunina fully supported the prosecutor's demand, and rubberstamped the commission's conclusion.

The December 1, 2011 court decision proclaimed that ChK in Ukraine contained extremist materials. The decision was reached in the absence of the authors. ${ }^{33}$ A year later, Shapoval, one of the authors, was asked to comment on the trial in absentia. He stated that he and his coauthors "write neither anti-Russian nor extremist books," and that the accusation of the court appeared to him nonsensical. His task is simply to do research and to write books, he explained. Thus, he had no intention of contesting such allegations. ${ }^{34}$ There was, however, a critical voice in the court room: Natalia Sharina, the director of the Moscow Library of Ukrainian Literature at the time. Sharina whose library had a copy of the book argued that the linguists' conclusion had no logical or factual foundation, suggesting that it should be dismissed because it lacked credibility. She also emphasized that according to the law of the Russian Federation, censorship was never a function of public knowledge repositories, such as libraries, and that her personal professional responsibilities did not include searching for extremist statements in publications located in her library. Moreover, she stated, it would be problematic for her to identify any such statements. ${ }^{35}$ Sharina's objections, however, had no effect on the court presided over by Judge V. P. Proshchenko.

In delivering his decision, Proshchenko first provided a definition of extremist activity and extremist materials:

According to the 25 July 2002 Federal Law no. 114-F3 (Article 1, Part 1)"About Countering Extremist Activities," extremist activities (extremism) should be understood as activities aimed at igniting social, racial, national or religious hatred; propaganda of exceptionality, superiority or inferiority of people, and the violation of human rights, freedoms and people's natural interests because of their social, racial, national, religious or linguistic identity; public calls to implement actions mentioned above or mass distribution of extremist materials and their production and storage for distributing purposes. ${ }^{36}$

The text above reveals that the definition of extremism is very broad and almost allinclusive. It locks judges within the space of ideologies, stereotypes, and subjectivities. The criteria of identifying individuals who would qualify as "extremists" have not been provided

\footnotetext{
$3^{31} \quad$ "Informatsiia po delam i sudebnym aktam."

$3^{2} \quad$ See the opening paragraph of the verdict, available at "Informatsiia po delam i sudebnym aktam."

33 Prystaiko, one of the authors of ChK in Ukraine, passed away on January 21, 2008 and did not have an opportunity to learn about Moscow's case.

34 Shapoval, "Rosiiske kerivnytstvo."

35 "Informatsiia po delam i sudebnym aktam."

${ }_{36}$ "Informatsiia po delam i sudebnym aktam."
} 
which suggests inevitably arbitrary applications of the law. As many commentators have noted, in Russia's official use, the term "extremism" has become synonymous with political opposition. ${ }^{37}$ Political and social problems are being encoded in judiciary terms and definitions intentionally devoid of clear explanations, criteria, and typologies. Ironically, from this viewpoint, one might persuasively argue that political extremism has become a modus operandi employed by the contemporary Russian elite, a situation in which the elites' extremism produces profound ideological forms of nationalism cultivating a national-imperial model of governing based on a single official historical narrative. ${ }^{38}$ Importantly, the trial was brief, and without any deliberation, the Judge reached his conclusion on the basis of the linguistic commission's verdict. The fate of the book was sealed.

Documents or materials deemed to be extremist according to the 2002 Federal Law and defined as such by a court had to be confiscated immediately, from all locations within the territory of the Russian Federation. One of the repositories that carried the book was the Moscow Library of Ukrainian Literature. The court was unable to ascertain any specific guilty party or parties, and, ultimately, the entire staff of the library was held responsible for the storage and distribution of the "extremist" historical narrative. Interestingly, ChK in Ukraine has been available online at several sites, so the extraction of several hard copies from Russian libraries could not solve the problem of the book's "pernicious" influence on Russian citizens, a situation which highlights the ideological motivation for the book's criminalization.

Importantly, the attack against ChK in Ukraine should be considered in the context of a broader persecution of Ukrainian organizations in Russia, including the Moscow Library of Ukrainian Literature. Shapoval has claimed that this is a part of the project under the current administration aimed at rejuvenating imperial traditions and practices in Russia. ${ }^{39}$ Hostility toward Ukrainians and Ukraine as a state and the desire to reclaim it as a part of the Russian Federation has been recently confirmed and reinforced by the annexation of Crimea and Russia's military actions in Eastern Ukraine. Today the Moscow Library of Ukrainian Literature is threatened with closure; its director Sharina has been charged with extremism and placed under domestic arrest; and those individuals who in the past ordered the library's books on the Holodomor or Yevhen Hutsalo's book Mentalnist ordy (The Horde's Mentality) are on the FSB's most wanted list. ${ }^{40}$ On March 22, 2016, the Moscow city court extended Sharina's domestic

37 Alexander Osipov, "Ethnicity, Discrimination and Extremism in Russia," Problems of Post-Communism $57.2(2010): 55$.

$3^{8} \quad$ Emil A. Pain, "Xenophobia and Ethnopolitical Extremism in Post-Soviet Russia: Dynamics and Growth Factors," Nationalities Papers 35.5 (2007): 895-911.

39 Shapoval, "Rosiiske kerivnytstvo."

40 Grigorii Tumanov, "Biblioteku ukrainskoi literatury v Moskve mogut likvidirovat [The Library of Ukrainian Literature Might be Closed]," Kommersant.ru, 2015, accessed March 28, 2016, http:// kommersant.ru/doc/2882950; "Visitors of Ukrainian Library in Moscow Wanted by Police," Ukraine Today, April 12, 2016, accessed May 5, 2016, http://uatoday.tv/politics/visitors-of-ukrainian-library-inmoscow-wanted-by-police-629267.html. 
arrest until April 28, 2016. ${ }^{41}$ Sharina's lawyer Ivan Pavlov is convinced that "this case's special character is revealed in the word 'Ukraine' - everything associated with Ukraine is special and politically motivated." 42

Furthermore, the criteria employed for evaluating ChK in Ukraine as extremist literature, which were supposed to guide the experts of the commission, were in fact never presented in court. Questions about how the commission members had reached their conclusion and what methodology each member of the commission had used to analyze the text remain a mystery. No detailed analysis that might have deconstructed the text from cultural, linguistic, and/or semantic perspectives was discussed during the court hearing. In fact, none of the members of the commission was present in court during the hearing, and Sharina, the sole person questioning the court decision, was given no opportunity to ask them any questions regarding their evaluations. Yet, the trial conducted in the absence of the members of the commission and the authors of the book produced a court decision that included a reference to the "totality" of the evidence (sovokupnost dokazatelstv) in this criminal case, a "totality" that was grounded in the one conclusive statement of the commission from the Russian Academy of Sciences. ${ }^{43}$

For those whose specialty is neither jurisprudence nor linguistics, but who nonetheless have some familiarity with Soviet history, the court hearing that took place on December 1, 2011 in the Meshchanskii District Court resembles the trials in absentia held all over the Soviet Union in 1937-1938. Inviting the "guilty" to participate in the hearing or providing anyone with an opportunity to cross-examine the linguists, members of the commission, appears never to have been considered by the court. Yet, there is a difference: instead of the usual troika that routinely sentenced the accused to death during the Great Terror, often in their absence and in the absence of witnesses or a jury, the decision in this 2oncase was left to one individual Judge Proshchenko who decided the fate of the book.

Following the logic of the court decision, the documents issued by the central organs in Moscow (including the NKVD) which were subsequently included in the "extremist" book ChK in Ukraine should also be considered extremist. Correspondingly, the signatories of these documents in the 1930s - specifically, Nikolai Ezhov and Mikhail Frinovskii (the NKVD leadership), who ordered the arrests of Poles, Germans, Lithuanians, Romanians, Finns, Bulgarians, Greeks, and Ukrainians, - also contributed to "national hatred" and should thus be considered guilty of

${ }_{41} \quad$ "Sud priznal zakonnym prodlenie sroka domashnego aresta Natalie Sharinoi [The Court Extended Natalia Sharina's Domestic Arrest]," Memorial, 2016, accessed March 28, 2016, http://memohrc.org/ news/sud-priznal-zakonnym-prodlenie-sroka-domashnego-aresta-natale-sharinoy. For more details on the criminalization of the Moscow Library of Ukrainian Literature, see the comments by Vasilii Duma, a member of the Council of Federations of the Russian Federation from the Kostroma oblast in "'Bibliotechnyi skandal' - eto odioznaia politicheskaia provokatsiia [The 'Library Controversy' is an Odious Political Provocation]," Ofitsialnyi sait chlena Soveta Federatsii RF ot Kostromskoi oblasti, 2015, accessed March 30, 2016, http://www.vduma.ru/article.php?id=316.

${ }_{42}$ Quoted in Howard Amos, “We are Worried About the Books': Kremlin Targets Moscow's Ukrainian Library," IBT, 2016, accessed March 28, 2016, http://www.ibtimes.com/we-are-worried-about-bookskremlin-targets-moscows-ukrainian-library-2301219.

43 "Informatsiia po delam i sudebnym aktam." 
the same crime as the 2011 defendants. But to the contemporary Russian political leadership, the authors of ChK in Ukraine are deemed fundamentally superior extremists, simply because they had made these archival documents available to the public. ${ }^{44}$ One might have hoped after more than seventy years had passed that the infamous procedures of Stalinist courts would have faded from Russian jurisprudential practices. They, however, persist, and handy operative terms such as "extremism" are stretched and manipulated to condemn careful historical studies, such as the one written by Shapoval, Prystaiko, and Zolotariov. ${ }^{45}$ The decision reached in haste confirms the vitality of Stalinist traditions in Russia when it comes to identifying the guilty, punishing them, and, most importantly, using mass propaganda for the state's political ends.

Such Russian practices are not unique. Slavoj Žižek has contended that in the former Yugoslavia the Criminal Code contained the infamous Article 133, which stipulates that any writer or journalist (and anything written by them) may be criminalized and prosecuted. From this perspective, the texts (and their authors) could be found "guilty" of arousing "tension and discontent among the public," and of false representations of socialist achievements. ${ }^{46}$ The deliberate vagueness of the relevant definitions extended the circle of potential transgressors: they could be applied to anyone and anything, making, if necessary, "everyone [...] guilty of something." ${ }^{47}$ Russia's 2002 Federal Law was designed in a similar fashion, becoming a powerful weapon for the Russian government to use against opposition and dissent. It was, moreover, a law that could even be applied and implemented across national borders.

\section{Memorial's Involvement}

The International historical and civil rights society Memorial became a part of the microhistory of ChK in Ukraine. 48 The December 23, 2010 raid on the Moscow Library of Ukrainian Literature (as well as the most recent one on October 28, 2015), during which the Department on Combating Extremism of the Ministry of Internal Affairs of the Russian Federation seized all

$44 \quad$ Shapoval, Prystaiko, and Zolotariov, ChK-GPU-NKVDv Ukraini, 347-50, 387-88.

45 The term "extremists" seems to share a heritage with early Soviet pejorative euphemisms such as "kulaks" and "enemies of the people."

${ }_{46} \quad$ Slavoj Žižek, Violence (New York: Picador, 2008), 159.

47 Žižek, Violence, 158-59.

48 Jonathan Sanders identified Memorial as a "seedbed of activism," and "the foremost informal organization fomenting what became the self-liberation of Soviet society." Since its founding in 1987 in Moscow, Memorial accumulated a substantial collection of various materials that necessitated the creation of an archive, a museum and a library. Today the Moscow Memorial library has approximately 30,00o books in various languages, including Ukrainian. Scholars, writers and journalists who study the history of authoritarian and totalitarian regimes are among its regular patrons. Memorial is not an anti-state organization; rather its activists fight against Stalinism, Soviet legacies and state violence. Yet, relations between Memorial and the authorities have always been uneasy. See Jonathan Sanders, "Foreword," in Victims of Soviet Terror: The Story of the Memorial Movement, ed. Nanci Adler (Westport, Connecticut: Praeger, 1993), xi, xii; see also Memorial's Official Site, Memorial, accessed March 28, 2016, http://www.memo.ru/. 
publications that appeared in the Library's catalogue under the rubric "nationalism," mirrored the December 4, 2008 raid on the Memorial Research and Information Centre in St. Petersburg, which resulted in the confiscation of the center's electronic archive. ${ }^{49}$

Under Medvedev's presidency, the actions of members of the Public Prosecutor's Office in St. Petersburg shook the democrats in Russia, as well as members of the international scholarly community. A description of Memorial's unique archival collection, which had been accumulated through the efforts of a great number of people over the course of more than twenty years of diligent research, seems particularly relevant here:

A total of eleven hard drives were confiscated. These drives hold several databases containing: biographical information on more than 50,00o victims of Stalinist repression; the results of the search for execution and burial sites of victims of repression (several hundred sites described or photographed); the photo collection (over 10,000 photographs) and accompanying textual material of the "Virtual Gulag Museum," which is a unique online source linking more than one hundred local Russian museums. Also confiscated were the database of the oral history archive and an electronic collection of photographs, including scans of historic materials from private archives. ${ }^{50}$

According to Russian scholar Ella Paneiakh, the actions of the silovye struktury or siloviki ${ }^{51}$ in Memorial headquarters were both illegal and rather violent. She has argued that this incident proved once again that the state was attempting to lobotomize societal memory.52 Similar

49 On December 5, 2008, 259 internationally recognized scholars signed an open letter of protest addressed to President Dmitry Medvedev. See the open letter to Medvedev at Xindex: The Voice of Free Expression, 2008, accessed March 28, 2016, http://www.indexoncensorship.org/20o8/12/an-openletter-to-president-medvedev/.

50 "Open Letter to Medvedev."

${ }^{51} \quad$ Silovye struktury in Russia, as in Ukraine, maintain their key function as a repressive apparatus, and the pattern of their operational tactics can be traced to those of the ChK/NKVD/KGB. Alexander Etkind offered a definition of siloviki as "violence specialists," or "masters of violence." See Alexander Etkind, “The Kremlin's Double Monopoly," in Russia Lost or Found? Patterns and Trajectories, eds. Haski Haukkala and Sinikukka Saari (Helsinki: Edita, 2009), 199-200; Fedor, Russia and the Cult of State Security, 4-5. On silovye struktury in Ukraine, see Taras Kuzio, "Ukraine's Security Forces: Bloated, Incompetent and Still Neo-Soviet," Eurasia Daily Monitor, February 6, 2013.

$5^{2} \quad$ Ella Paneiakh, "Zachem prokurature 'Memorial'? [Why Does the Prosecutor's Office Need 'Memorial'?]," Polit.ru, 2008, accessed March 28, 2016, http://www.polit.ru/article/2008/12/10/ memorial1/. After nearly a six-month legal battle, Memorial's archive was returned by the authorities. Most interestingly, Medvedev's appointee, the Permanent Representative of Russia to the Organization for Security and Co-operation in Europe (OSCE) Anvar Azimov made a public statement in Austria that the search in the Research and Information Centre Memorial in St. Petersburg was conducted in the context of investigative activities of organizations that "ignited extremism," and that the authorities had grounds to believe that "Memorial' financially 
patterns that the state employed in accusing Memorial and its library of supporting extremist activities provoked anxiety among Memorial's staff who endeavored to clarify the essence of such accusations with the Meshchanskii District Court. ChK in Ukraine became the focal point of correspondence between Memorial and the court, as Memorial's library also had the book in its collection.

The nonresponsive silence of state institutions eventually forced the director of the Memorial library, Boris Belenkin, to take the initiative and request a copy of the court decision six months after the verdict was issued. He asked Sergei Selevestrov, the chair of the Meshchanskii District Court, for information about the alleged extremist essence of ChK in Ukraine, which, as Belenkin stated, was quite popular among the researchers who worked in the Memorial library and which remained one of the most quoted publications among historians conducting research on the Soviet secret organs in the 1920s and the 1930s. Besides a copy of the court decision, Belenkin also requested a copy of the conclusion that had been provided to the court by the commission from the Russian Academy of Sciences. ${ }^{53}$ Had he continued to circulate ChK in Ukraine among his customers after December 1, 2011, he would have been held fully responsible for violating the court decision. Belenkin stressed that he needed legal documents that would give him a legitimate reason to take the book out of circulation. In addition, he argued that a written conclusion of the linguists' commission would enlighten him about possible explanations he might offer any researchers inquiring about this particular publication. ${ }^{54}$

Belenkin received an immediate response to his request..$^{55}$ However, this response only included a copy of the court decision. No explanations about why the court had failed to send a copy of the linguists' conclusion were forthcoming. Ultimately, as a result of the Meshchanskii District Court's decision, ChK in Ukraine was purged from the holdings of at least two libraries in Moscow, the Library of Ukrainian Literature and the Memorial library. A few hard copies of the book may have survived, but only in private collections of Russian scholars who are specialists in the history of the Soviet secret police.

Shapoval has noted that the Memorial staff intended to fight the decision and to defend the publication in court. ${ }^{56}$ However, the marginalization of Memorial at home and the state's actions aimed at branding the organization as extremist prevented Memorial from carrying out this intention. In a sense, the Memorial staff and the authors of ChK in Ukraine found themselves in the same boat. Both were silenced and criminalized, the only difference being that the former had been sanctioned - unofficially and the latter - officially. More to the point is the fact that the parties involved were citizens of two different states, a deterrent to any potential joint legal struggle against the state's accusations of extremism. A noteworthy sequel to these events is

supported extremist activities." For more details, see Konstantin Andriianov, “'Memorialu' vernuli kompiuternuiu pamiat [The Computer Memory Was Returned to Memorial]," Kommersant.ru, 20o9, accessed March 28, 2016, http://www.kommersant.ru/doc-rss/1167417.

53 The official letter of Memorial to the Meshchanskii District Court is dated May 28, 2012.

54 Photocopies of correspondence between Belenkin and Selevestrov are in the author's possession.

$55 \quad$ The Meshchanskii District Court sent Belenkin the document on June 4, 2012.

${ }^{5} 6 \quad$ Shapoval, "Rosiiske kerivnytstvo." 
that an invitation sent to Belenkin requesting him to comment about the charges against the Ukrainian publication remained unanswered. ${ }^{57}$ His silence on this matter is not surprising as any comments, especially if made in writing, might also be construed by the Russian authorities as a manifestation of extremism and result in unwelcome ramifications for the commentator. Sharina's imprisonment in late October 2015, for example, highlights this viewpoint.

As it had in the Soviet Union, the new uses of vocabulary in Russian criminal law clearly reflect changes in ideology, politics, and cultural patterns established by new political leaders. ${ }^{58}$ The Russian authorities continue to seek out and use terminology that effectively helps them expand the boundaries of individual guilt before the state, and inflates the seriousness of purported transgressions. The Extremism Law forbids extreme political positions and actions but the question remains: who identifies the boundaries between "normal" and "extreme" political behavior? A skillful politician and/or a demagogue in charge can effortlessly adjust, skew, or stretch a broad definition of extremism codified by the law to accommodate his or her political ends. Moreover, the manipulation of the term and its public discussion blankets and shapes media and popular opinion..$^{59}$ Court decisions further legitimize and finalize the "correct" understanding of the term in each case. Vladimir Shlapentokh has noted that

among the various elements of the Soviet system, the political machine was by far the most efficient. Essentially, the system worked as an effective tool for achieving the goals set by the general secretary and the ruling political elite. 60

The Sovietized model of the "political machine" in the Russian Federation continues to preserve this efficiency when it comes to intimidating, neutralizing, and ultimately silencing the opposition. Russian political leaders have thus exhibited an amazing resilience and loyalty to Soviet traditions and habits by creating a language of exclusion, a reliable tool that helps maintain the high efficiency of this political model.

\section{Managing National Memory}

The process of rewriting and sanitizing the national historical narrative in Russia was not initiated in 2010 or in 1991 after the fall of Communism. Cultural mythologies glorifying Russian

57 The author's e-mail message to Boris Belenkin, December 27, 2013.

${ }^{8} \quad$ For a discussion about Stalinism and Soviet legal culture, see Robert Sharlet, "Stalinism and Soviet Legal Culture," in Stalinism: Essays in Historical Interpretation, ed. Robert C. Tucker (New York: W. W. Norton \& Company, Inc., 1977), 173.

59 Putin has recently dissolved the official state news agency, RIA Novosti, and announced the creation of Rossiia Segodnia (Russia Today). Dmitry Kiseliov, famous for his personal loyalty to Putin, was appointed as the new media agency head: "Putin's decree said the main focus of Rossiia Segodnia 'is to highlight abroad the state policy and public life of the Russian Federation." See "Russia Regresses," The Boston Herald, republished in Press Enterprise, December 24, 2013, 18.

6o Vladimir Shlapentokh, A Normal Totalitarian Society: How the Soviet Union Functioned and How it Collapsed (New York: M. E. Sharpe, 2001), 101. 
history had been written long before the history of Russia was constructed by Russian historians Aleksandr Barsenkov and Aleksandr Vdovin in 2010. The most fundamental and memorable attempts to change the narratives of Russian history were undertaken in the 19th century by two Russian thinkers and historians Vasilii Kliuchevskii (The Course of Russian History in five volumes) and Nikolai Karamzin (History of the Russian State in twelve volumes). ${ }^{61}$ Karamzin's Russo-centric views were criticized by many of his contemporaries. ${ }^{62}$ Interestingly enough, during the first part of the 19th century, Russian authorities made use of Karamzin's history because it underpinned the "official historical doctrine" that served the needs of the state. ${ }^{63}$ R. R. Garagozov has argued that a "schematic narrative template" is a social construct created to shape collective memory to fight external enemies, and this template was constantly reinforced and shaped by history itself in Russia. The interaction of many factors played a role in its creation and in writing a "new historical narrative [...] which still directs people to search for enemies and to make war against "hostile forces." 64 Ideology and politics are always paramount in this process, underscoring the continuity and the vitality of the construct.

For various reasons, including an ideological one that reinforces a concept of great Russia, its inimitable historical path, and unique Russian identity, Russian history has been rewritten not only by historians, artists, writers, and film directors but also by politicians. ${ }^{65}$ Authoritarian leaders, such as Stalin, greatly contributed to rehabilitating the vicious Tsar Ivan IV, and

${ }_{61} \quad$ On cultural mythologies in Russian history, see Aleksandr Maslov and Aleksei Maslov, Smertelnyi tron: Zagadki poslednikh dnei pravitelei Rossii [The Lethal Throne: The Mysteries of the Last Days of Governors in Russia] (Moscow: Feniks, 2010).

62 The most vigorous critics of Karamzin's Istoriia were the Decemberists Nikita Muraviov and Mikhail Orlov. See L. I. Vilde and M. V. Nechkina, “Dekabrist Mikhail Orlov — kritik 'Istorii’ N. M. Karamzina,” Literaturnoe nasledstvo 59 (1954): 557-68. Nikolai Polevoi, a Russian critic and journalist, blamed Karamzin and other historians for their Russo-centric views in regards to Ukraine which had "decisively, not ours, but a separate nationality." Quoted in Serhiy Bilenky, Romantic Nationalism in Eastern Europe: Russian, Polish, and Ukrainian Political Imaginations (Stanford, CA: Stanford University Press, 2012), 224.

$63 \quad$ R. R. Garagozov, “Collective Memory and the Russian 'Schematic Narrative Template.” Journal of Russian and East European Psychology 40.5 (2002): 86.

${ }_{64}$ Garagozov, "Collective Memory," 87. For a discussion about rewriting history in Russia during the post-Stalinist period, see Roger D. Markwick, Rewriting History in Soviet Russia: The Politics of Revisionist Historiography, 1956-1974 (New York: Palgrave, 2001).

${ }_{65}$ Scholars have been joined by "an army of popular and amateur historians" or "pseudo-historians" who reinvented Russia's past. See, for instance, Konstantin Sheiko's analysis of Anatolii Fomenko's works: Konstantin Sheiko (in collaboration with Stephen Brown), Nationalist Imaginings of the Russian Past: Anatolii Fomenko and the Rise of Alternative History in the Post-Communist Russia (Stuttgart: Ibidem-Verlag, 2009), 11, 19, 20. Similar trends can also be observed in regards to Ukrainian history. For a discussion about memory politics in Ukraine, see Volodymyr V. Kravchenko, "Ukraine Faces its Soviet Past: History versus Policy versus Memory," in Mass Dictatorship and Memory as Ever Present Past, eds. Jie-Hyun Lim, Barbara Walker and Peter Lambert (New York: Palgrave Macmillan, 2014), 87-119. 
Stalin's attempts at changing the history of the $\operatorname{VKP}(\mathrm{b})$, the All-Union Communist Party (Bolsheviks), are well documented. ${ }^{66}$ The Russian political elite's efforts to create a national historical narrative that would fit its agenda traditionally materialized in history textbooks that, as David Brandenberger has fittingly noted, "have long played an unusually political role in Russo-Soviet society, serving as a mechanism for indoctrination from above and a metaphor for authoritarian heavy-handedness for those below."67 In the mid-20oos, the presidential administration sponsored and provided conceptual outlines for narrating a post-war Soviet/ Russian history in A. V. Filippov's and A. A. Danilov' s textbooks. Significantly, a consideration of any Russian historical narrative inevitably entails analyses of contemporary Russia as a Russia that has positioned itself as a guardian of a "positive perspective" and commensurate view of Russian history in general. ${ }^{68}$ Following Stalin's tradition, Russian leaders have enthusiastically shaped a single historical narrative that "impedes the emergence of an inclusive post-repression narrative." 69

This narrative mythologizes a Russian/Soviet national history and rehabilitates Stalin who, engaged in far-reaching repressions, has been depicted as a great political leader and manager. The decision to rejuvenate Stalin's symbolic significance in the Russian state (i.e., an ode to Stalin found in one of the Moscow metro's stations installed in 2009, and the display of Stalin's images on the exteriors of public transportation vehicles in various Russian cities $)^{70}$ is evidence of the deliberate obstruction of historians' efforts to write a history of Stalin's repressions and the chekists who implemented them.

The chekists' untouchable status is maintained by creating a dome of silence over their crimes. In cases in which Russian authorities can no longer deny them, such crimes seem to have been committed by unidentified persons, and the state prefers to keep it this way. The treatment of the 1940 Katyn massacre of Polish officers held in Soviet captivity is very instructive in this respect. In November 2010, the Russian Parliament acknowledged that Stalinism was

66 Istoriia Vsesoiuznoi kommunisticheskoi partii (bolshevikov): Kratkii kurs [The History of the All-Union Communist Party, the Bolsheviks: A Brief Course], ed. the Commission of the Central Committee of the VKP(b) (Moscow, 1938); David Brandenberger and Kevin M. F. Platt, "Terribly Pragmatic: Rewriting the History of Ivan IV's Reign, 1937-1956," in Epic Revisionism: Russian History and Literature as Stalinist Propaganda, eds. David Brandenberger and Kevin M. F. Platt (Madison: University of Wisconsin Press, 2006), 157; David Brandenberger, "A New Short Course?: A. V. Filippov and the Russian State's Search for a 'Usable Past," Kritika: Explorations in Russian and Eurasian History 10.4 (2009): 825-33; Stephen M. Norris, Review of Pavel Lungin's Tsar, 2009, Kinokultura 28 (2010), accessed March 28, 2016, http://www.kinokultura.com/2010/28r-tsar-sn.shtml.

${ }_{67} \quad$ Brandenberger, "A New Short Course?" 825.

68 Nanci Adler, "Reconciliation with — or Rehabilitation of — the Soviet Past," Memory Studies 5.3 (2012): 328 .

69 Adler, "Reconciliation," 328.

$7^{\circ} \quad$ Aleksei Yaroshevskii, "Stalin vernulsia v Moskovskoe metro [Stalin Returned to Moscow's Subway]," Russia Today, 2009, accessed March 28, 2016, http://inosmi.ru/video/2009o9o4/252288.html; "Bitva za Stalina [The Battle for Stalin]," Interfax, 2011, accessed March 28, 2016, http://www.interfax.ru/ print.asp?sec $=1448 \& i d=18783$. 
responsible for the crime. ${ }^{71}$ Putin, however, emphasized that Russians could not be blamed for the Katyn massacre. ${ }^{72}$ Labeling those chekists who participated in the massacre as criminals, let alone identifying the state's accountability for this crime, was not even considered. Putin's return to presidency in 2012 marked an unequivocal rejection of the de-Stalinization program, attempts undertaken under Medvedev. Russia's attitudes toward this crime committed by the Soviet government, as well as toward the Nazi-Soviet collaboration that resulted in the MolotovRibbentrop Pact, present a "litmus test" for Russia's democracy. ${ }^{73}$ It was only through the efforts of historians and progressive-minded associates of secret organs that the Katyn tragedy gained a clearer contour: the March 5, 1940 Decree of the Politburo of the Central Committee of the VKP(b) sentenced to death 21,857 Polish citizens. ${ }^{74}$ The uneasy process of de-classifying archival documents illuminating the Soviet state and chekists as agencies that committed horrendous crimes against humanity (as well as the Moscow courts' rejections of financial claims made by Katyn families) reveals the ongoing persistence by the current Russian leadership to sanitize the Stalinist past. ${ }^{75}$

An inclusive historical narrative of Soviet state-sponsored terror should consider not only the story of victims and survivors but also the story of the perpetrators of the crimes against humanity — the Soviet secret police. ${ }^{76}$ However, the state defends esprit de corps (chest mundira), constructing official memories about the past and downplaying the popular memory of Stalin's repression. ${ }^{77}$ Criminalizing ChK in Ukraine, which exposed chekists' violence, seems to be consistent with the other measures taken by the Russian government designed to control the historical narrative. The Extremism Law is one of Russia's illiberal actions and legislation ${ }^{78}$ that helps preserve the status quo and create new definitions that defame the opposition and glorify

${ }^{71} \quad$ Alexander Etkind et al., Remembering Katyn (Cambridge, UK: Polity Press, 2012), 144; Adler, "Reconciliation," 331.

${ }_{72}$ "Blame for Massacre of Poles Cannot Be Put on Russians — Putin," RT, 2010, accessed March 28, 2016, https://www.rt.com/politics/katyn-poloes-massacre/.

$73 \quad$ Etkind et al., Remembering Katyn, 95.

74 Semen Zavortnov, Kharkovskaia Katyn [Kharkiv's Katyn], 2nd ed. (Kharkiv: Konsum, 2004), 129; Anna M. Cienciala, Natalia S. Lebedeva, and Wojciech Materski, eds., Katyn: A Crime Without Punishment (New Haven; London: Yale University Press, 2007), 121; Etkind et al., Remembering Katyn, 1.

75 Etkind et al., Remembering Katyn, 104, 107. On January 26, 2011, the Russian Supreme Court declined Memorial's appeal to reconsider the Moscow court's decision about de-classifying archival materials linked to the Katyn massacre.

${ }_{76} \quad$ Adler, "Reconciliation," 335.

77 Nanci Adler, "The Future of the Soviet Past Remains Unpredictable: The Resurrection of Stalinist Symbols Amidst the Exhumation of Mass Graves," Europe-Asia Studies 57.8 (2005): 1093-1119.

${ }_{78} \quad$ For a discussion about contemporary Russia's illiberal state policies and imperial strivings (the author traces them since the Soviet victory in World War II), see Stephen Lovell, The Shadow of War: Russia and the USSR, 1941 to the Present, in the series The Blackwell History of Russia (Chichester, West Sussex, UK; Malden, Mass.: Wiley-Blackwell, 2010), 282-84, 286, 316-17, 319. 
those who supposedly righteously guard the law, ranging from the various siloviki (spetsnaz, OMON, Alpha Group and the like) to judges in court rooms. ${ }^{79}$

Putin inspires popular support for the official historical narrative by inciting Russian patriotism and nationalism, and by encouraging Soviet nostalgia. ${ }^{80}$ Famously, the Russian leader has opined that the collapse of the Soviet Union was "the greatest geopolitical catastrophe" of the 2oth century. ${ }^{81}$ The glorification of the heroism of the Russian nation during "the Great Patriotic War" serves Putin as a reliable and constant aid. ${ }^{82}$ Moreover, Russia's recent political and cultural trends repeatedly and consistently seem to refute Sheila Fitzpatrick's 2004 conviction that the Great Patriotic War is steadily losing its central place in Russian collective memory. ${ }^{83}$ The Russian leadership routinely reinforce national memory about World War II as "pre-eminently a Russian national symbol" that facilitates "national self-discovery" for Russian citizens. ${ }^{84}$ The film industry and film directors, such as Nikita Mikhalkov and Fedor Bondarchuk, have greatly contributed to the narrative of Russian glory and heroism during "the Great Patriotic War," and support a neo-imperial ideology. Another of Putin's acolytes, Russian pop-singer Oleg Gazmanov, facilitates the President's effort to romanticize the image of the Soviet Union, Soviet manhood, and Russian/neo-Soviet patriotism through his hit song "Sdelan v SSSR" (Made in the USSR). ${ }^{85}$ The creative work of Mikhalkov, Bondarchuk, and Gazmanov is immensely popular in Russia, but, not surprisingly, provokes skepticism and even hostile reactions in some former Soviet republics. ${ }^{86}$

79 This image has been enhanced by the Russian court TV shows, such as "Chas suda" (the Russian REN TV) with Judge Pavel Astakhov, a lawyer and alumnus of the Highest KGB School, in charge.

so Lovell, The Shadow of War, 319 .

81 "Putin Deplores Collapse of USSR," BBC News, accessed 29 March 2016, http://news.bbc.co.uk/2/ hi/4480745.stm.

${ }_{22}$ "A war of national liberation" is emphasized, and "a war of imperial expansion" is de-emphasized. See Lovell, 316. For more details on the nature of contemporary Russian nationalism, and the relationships among historical memory, national identity, and monuments, see Benjamin Forest and Juliet Johnson, "Unraveling the Threads of History: Soviet-Era Monuments and Post-Soviet National Identity in Moscow," The Annals of the Association of American Geographers, 2001, accessed March 29, 2016, http://www.dartmouth.edu/ crn/crn_papers/Forest-Johnson.pdf; on contemporary Russian nationalism and the ideological opera "Crimea" that celebrates and glorifies the annexation of Crimea see Tatiana Voltskaia, "Krym kak lozung i aria [Crimea as Propaganda and an Aria]," Radio Svoboda, 2014, accessed March 29, 2016, http://www.svoboda.org/content/article/25452116.html.

$8_{3} \quad$ Sheila Fitzpatrick, "Introduction: Soviet Union in Retrospect — Ten Years after 1991," in The Legacy of the Soviet Union, eds. Wendy Slater and Andrew Wilson (Basingstoke: Palgrave Macmillan 2004), 9.

${ }^{84}$ Lovell, The Shadow of War, 319. See also "Putin: Rossiia pobedila by v voine i bez Ukrainy," Fokus. UA, 2010, accessed March 30, 2016, http://focus.ua/politics/161151.

${ }_{85}$ See Gazmanov's interview in which he boasts about his closeness to Putin: "Oleg Gazmanov: K Putinu khozhu v futbolke [Oleg Gazmanov: I Visit Putin Wearing a T-Shirt]," Sem4o.ru, 2003, accessed March 29, 2016, http://www.sem40.ru/famous2/m1866.shtml.

86 For details about the recent protest of Lithuanian and Latvian state officials against Gazmanov's song "Sdelan v SSSR" he performed in Vilnius (Vilno) on December 29, 2013, see “'Sdelan v SSSR': 
Historically, the national aspirations of Russia's neighboring states have never limited the advance of Russian domination over their territories. ${ }^{87}$ The ideas of Pan-Slavism and memory politics continue to play an important role in inflaming the imperial consciousness among the Russian population, and in ideological subversion of people in Ukraine and other former Soviet republics. These ideological tools are the focal point of today's Russian political culture. As in the late 1920 s and 1930s, the Kremlin's course and its attempts to rewrite Ukrainian history are rather aggressive and anti-Ukrainian. ${ }^{88}$ ChK in Ukraine is not the only Ukrainian publication criminalized by a Russian court. The Russian government carefully regulates the presence of Ukrainian "extremist" publications in Russian bookstores and libraries, i.e., literature that might challenge the official Russian historical narrative. Recently, a number of Ukrainian publications have been included on the aforementioned Federal List of Extremist Materials. The Meshchanskii District Court appears to be the main source for banning "extremist" Ukrainian publications. Among them are works by Yaroslav Stetsko, Yaroslav Svatko, Hryhorii Hnarchuk, Serhii Zhyzhko, Petro Duzhyi, Stepan Mudryk, Andrei Sheptytskyi, Lev Rebet, Dmytro Korchynskyi, Dmytro Pavlychko, Petro Mirchuk, Dmytro Dontsov, Yuri Boiko, Mykola Mikhnovskyi and many others. ${ }^{89}$ Moreover, the Russian tactics in the East of Ukraine over the last two years suggest that the Russian political leadership continues to believe that Ukrainian independence is a "very temporary phenomenon." 90

\section{Epilogue}

As this study has illustrated, contemporary Russian politics and the Extremism Law are not particularly conducive to democratic liberalism and liberal practices. ${ }^{91}$ Putin "has been actively

pesnia Gazmanova vozmutila Pribaltiku [Made in the USSR: Gazmanov's song Infuriated the Baltics]," Argumenty i fakty, January 4, 2014, accessed March 30, 2016, http://www.aif.ru/culture/ showbiz/1065724. The song was characterized as a weapon in an "informational war and [Moscow] official imperial politics.”

${ }_{87} \quad$ James Mace, "Geopolitical Implications of Ethnopolitics," in The Political Analysis of Postcommunism: Understanding Postcommunist Ukraine, ed. Volodymyr Polokhalo (College Station, TX: Texas A\&M University Press, 1997), 305.

88 Vasyl Lyzanchuk, “Kryvava 'yolka’ Yanukovycha [The Bloody Christmas Tree of Yanukovych]," Literaturna Ukraina, December 5, 2013, 5.

${ }_{89} \quad$ "Federalnyi spisok ekstremistskikh materialov."

9o Mace, "Geopolitical Implications of Ethnopolitics," 317. Since James Mace published his essay on ethnopolitics in 1997, it seems not much has changed in the relations between Russia and Ukraine.

${ }_{91} \quad$ Marcia A. Weigle, Russia's Liberal Project: State-Society Relations in the Transition from Communism (University Park: The Pennsylvania State University Press, 2000), 454; Lilia Shevtsova, "Political Leadership in Russia's Transformation," in Russia's Engagement with the West: Transformation and Integration in the Twenty-First Century, eds. Alexander J. Motyl, Blair A. Ruble, and Lilia Shevtsova (New York; London: M. E. Sharpe, 2005), 106-07; Peter Pomerantsev, Nothing is True and Everything is Possible: The Surreal Heart of the New Russia (New York: Public Affairs, 2014). 
eviscerating democratic institutions throughout his entire tenure in office" - authoritarian and even fascist trends seem predominant in Russia at present. ${ }^{92}$ As far as state legislation is concerned, it seeks to force awareness of the crimes of Stalinism to the margins of collective memory.

The Russian authorities' and the FSB's intimidation tactics practiced since the beginning of the new millennium should not be viewed as incredibly sophisticated or veiled. On the contrary, they appear rather traditional and transparent. Among other strategies, the demoralization and destabilization of the intellectual elite in neighboring states, those who try to set the historical record straight, have been a routine procedure of the Russian secret services that was established in the late 195 os as a key component of ideological subversion or psychological warfare. These tactics have been applied since then at the state and individual levels, and refined in the territories strategically significant to Russia. ${ }^{93}$

Moreover, the repression of intellectual societal trends, including historical achievements of scholars and civic organizations, such as Memorial, is a manifestation of the anti-intellectualism of the current Russian political system that appears to be deeply rooted in Soviet traditions of control and coercion. ${ }^{94}$ Significantly, the authoritarian style of governing is hardly covert. It has, in fact, been emphasized through non-verbal and verbal messages perceived by the majority of the Russian public as a positive, savvy, and effective political approach to "repairing" things in Russia. ${ }^{95}$ Both obscure definitions and legislation play a significant role in creating the image of a powerful state, an emotional appeal capable of deceiving the broader public domestically and abroad.

The court decision that cast ChK in Ukraine as extremist literature presents clear evidence of Russia's intolerance of competitive historical narratives, and represents an attempt to erase the archival documents illustrative of Russian colonialism and chauvinism. Russia's attempt to normalize a discourse about the heroic Soviet chekists through legislation creates an "apocryphal legality" of Russia's current political system and trends, which in many ways began to resemble

${ }_{92} \quad$ Alexander J. Motyl, "Putin's Russia as a Fascist Political System," Communist and Post-Communist Studies 49.1 (2016): 32, 35. Motyl argues that four features are the key components of the fascist system of governing: full authoritarianism, mass support, a personality cult, and an active, personalistic leadership style, features that can be applied to Putin's Russia. Motyl, "Putin's Russia," 25.

$93 \quad$ The practices of ideological subversion were carefully explained by several Soviet defectors, including Yuri Bezmenov. See Yuri Bezmenov, “Deception Was My Job,” YouTube, 2011, accessed March 30, 2016, https://www.youtube.com/watch?v=y3qkf3bajd4.

$94 \quad$ These trends are also characteristic of the Ukrainian political elite who (as during the Soviet era) are highly suspicious of the intellectual elite, and critically thinking and "excessively smart" individuals (nadto rozumni). See Volodymyr Kravchenko, Ukraina, Imperiia, Rosiia: Vybrani statti z modernoi istorii ta istoriohrafii [Ukraine, Empire, Russia: Selected Essays on Modern History and Historiography] (Kyiv: Krytyka, 2011), 483.

$95 \quad$ For more details on the manipulation of popular opinion by the Putin regime, see Yuri Felshtinsky and Vladimir Pribylovsky, The Corporation: Russia and the KGB in the Age of President Putin (New York: Encounter Books, 2008). 
that of the Soviet system. ${ }^{96}$ Forcible amnesia or "institutionalized amnesia" 97 helps construct and strengthen a new patriotic Russian identity that is built through the public consensus about a new Russian national history.

Žižek has posited that "the position of power [...] involves new responsibilities." 98 The position of authoritarian power involves wars on all levels, including the ideological war for public memories, in which historians and the media become an extension of politicians' power. Since the onset of the Putin era, and this includes the 2001-2002 meetings of Russian historians with prime minister Mikhail Kasianov and president Putin in particular, this post-Soviet style of leadership has demonstrated the preferences of the current Russian political elite "to return to 'governed history' that would serve the short- and long-term political interests of the Russian elite."99 Stalin repressed the revolutionists and the historians of revolutions in an attempt to erase the authentic revolutionary past. In similar fashion, the current Russian leadership seeks to silence attempts by historians, whether inside or outside of Russia, to write histories of Soviet terror and repressions by criminalizing such histories. Thus, the legislation recently adopted in Russia shapes the nation's understandings of the past and cultivates people's intolerance for alternative historical narratives. Moreover, as Adler has suggested, being a historian has become a risky profession in Russia, and the work of those "who challenge the official narrative of present or past events [has] become more marginalized, and in some cases even dangerous." ${ }^{100}$

Like people, books may survive and flourish under one regime but be silenced under another. The fate of the Ukrainian scholarly publication ChK in Ukraine mirrors the death of democratic reforms in Russia: Yeltsin's Russia allowed it to live; Putin's Russia has criminalized and incarcerated it. The rules of the game have changed, and the mortality rate among books and journalists has dramatically increased. ${ }^{101}$ Mark Galeotti has noted that "Russia's great strength is because it breaks the rules and gets away with it [...] Internationally, Putin has an extraordinarily nuanced grasp of just how far he can push."102 Using Walter Benjamin's terminology, instead of culturalizing politics in tune with his routine claims of Russia's rapid modernization, Putin has pushed to politicize culture and history, even beyond Russia's national borders.

${ }_{96} \quad$ Vladimir Tismăneanu has observed a similar trend under Communism, when the non-democratic system cultivated an "apocryphal legality and contempt for the genuine rule of law." See Vladimir Tismăneanu, "Coming To Terms with a Traumatic Past: Reflections on Democracy, Atonement, and Memory," in History in Communism in Europe, ed. Corina Dobos and Marius Stan (Villejuit Cedex, FRA: Zeta Books, 2010), 16. See also Martin Malia, The Soviet Tragedy: A History of Socialism in Russia, 1917-1991 (New York: Free Press, 1994).

97 Tismăneanu, "Coming To Terms with a Traumatic Past," 20.

$9^{8} \quad$ Žižek, Violence, 121.

99 Leonid Zashkilniak, Suchasna svitova istoriohrafia [Contemporary World Historiography] (Lviv: PAIS, 2007), 215. Kasianov was fired by Putin in February 2004, and marginalized as a politician over the conflict with Putin about the arrests of Lebedev and Khodorkovskii. For details, see Masha Gessen, The Man Without a Face: The Unlikely Rise of Vladimir Putin (New York: Riverhead Books, 2012), 249-51.

100 Adler, "Reconciliation," 334.

$101 \quad$ Karen Dawisha, Putin's Kleptocracy: Who Owns Russia? (New York: Simon \& Schuster, 2014).

${ }_{102}$ Quoted in Waller, "Putin Celebrates Birth of KGB.” 
The culturalization of politics requires two elements: an educated and altruistic political elite, and democratic traditions that would support them, certainly a desirable feature for modern Russian democrats, such as Valeriia Novodvorskaia and Konstantin Borovoi. Before she passed away, Novodvorskaia had mocked Putin for portraying himself as another Stolypin who interestingly enough fought against left extremism, but for different reasons and by using different methods. Putin's war against "extremists," his politics, and politicized culture are not only anti-cultural, as Novodvorskaia and Borovoi have stated, but they have already propelled Russians into the streets to protest them. ${ }^{103}$

In 2005, in his annual state of the nation address to parliament, which was broadcast live on Russian television, Putin suggested that "Russia will pursue its own model of democracy." 104 The Extremism Law, the restoration of the image of Stalin as a manager and a revolutionary, and Putin's secret war in Ukraine to a large extent have clarified the essence of this model, and shed light on how Russian law structures national memory: the state forgives political prisoners of the Soviet regime for crimes they never committed, does not punish those who committed crimes against those who are rehabilitated, and downgrades the significance of an inclusive historical narrative for moral and intellectual societal advancement. ${ }^{105}$

Importantly, on November 20, 2014 at a meeting of the Russian Security Council, Putin updated Russia's vision on extremism by approving a draft Strategy for Countering Extremism in the Russian Federation Through 2025. The Strategy will monitor groups' and individuals' communication activities in social media, a risk-preventive measure against color revolutions that might provoke a regime change in Moscow. Nationalism was high on Putin's list of examples of extremism. Two key agencies drafted the security document, the Ministry of the Interior and the FSB. The document allocated a special role in information monitoring to Russian civil society, and especially to the scholarly community, who are expected to closely cooperate with the state. As some observers have argued, the new laws on extremism are "conceptually political," and designed to monitor social processes both in Russia and in its neighboring states to prevent Euromaidans. ${ }^{106}$

Putin's political agenda shaped Russian national memory politics. Once again, the multinational history of the Soviet Union has been reduced to a history of Russia and Moscow, and the parallels between Soviet and neo-Soviet authoritarianism in Russia have become more transparent. Although the state impetus for authoritarianism and historical amnesia is strong, some see contemporary Russian politics as "pre-lethal convulsions of the state." ${ }^{107}$ Pre-lethal or not, Russian memory politics have transcended national borders. They have, in fact, entered a

${ }_{103}$ Valeriia Novodvorskaia and Konstantin Borovoi, "Statia Putina," YouTube, 2012, accessed March 30, 2016, http://www.youtube.com/watch?v=05QftBi7HH8.

104 "Putin Deplores Collapse of USSR."

105 Nanci Adler, Keeping Faith with the Party: Communist Believers Return from the Gulag (Bloomington: Indiana University Press, 2012), 17, 19.

${ }_{106}$ Roger McDermott, "Putin Approves Draft Strategy for Countering Extremism in Russia to 2025," Eurasia Daily Monitor, November 25, 2014.

${ }_{107}$ Novodvorskaia and Borovoi, "Statia Putina." By "pre-lethal" Novodvorskaia and Borovoi meant implosion and ultimate destruction of Putin's regime. 
transnational phase, creating spaces for historical debates informed by Eurasianist ideas, which have silenced other valid ideas that have been generated by research, such as ChK in Ukraine. Most importantly, these memory politics promote and support military solutions in Ukraine and elsewhere, places where people have attempted to deconstruct and alter the imperial narrative and scenarios of development, so favored by the Russian political elite.

\section{Bibliography}

Adler, Nanci. Keeping Faith with the Party: Communist Believers Return from the Gulag. Bloomington: Indiana University Press, 2012.

Adler, Nanci. "Reconciliation with — or Rehabilitation of — the Soviet Past." Memory Studies $5 \cdot 3(2012): 327-38$.

Adler, Nanci. "The Future of the Soviet Past Remains Unpredictable: The Resurrection of Stalinist Symbols Amidst the Exhumation of Mass Graves." Europe-Asia Studies 57.8 (2005):1093-1119.

Amos, Howard. "We are Worried About the Books': Kremlin Targets Moscow's Ukrainian Library." IBT, 2016. Accessed March 28, 2016. http://www.ibtimes.com/we-are-worriedabout-books-kremlin-targets-moscows-ukrainian-library-2301219.

Andriianov, Konstantin. "Memorialu' vernuli kompiuternuiu pamiat [The Computer Memory Was Returned to Memorial]." Kommersant.ru, 20og. Accessed March 28, 2016. http:// ww. ommersant.ru/doc-rss/1167417.

Aslund, Anders. Ukraine: What Went Wrong and How to Fix It. Washington, DC: Peterson Institute for International Economics, 2015.

Baranov, A. N. Lingvisticheskaiia ekspertiza teksta: teoriia i praktika [Forensic Linguistics: Theory and Practice]. 4 ed. Moscow: Flinta-Nauka, 2012.

Bertelsen, Olga, and Myroslav Shkandrij. "The Secret Police and the Campaign against Galicians in Soviet Ukraine, 1929-34." Nationalities Papers: The Journal of Nationalism and Ethnicity 42.1 (2014): 37-62.

Bertelsen, Olga. "GPU Repressions of Zionists: Ukraine in the 1920s." Europe-Asia Studies 65.6 (2013): 1080-1111.

Bezmenov, Yuri. “Deception Was My Job.” YouTube, 2011. Accessed March 30, 2016. https://www. youtube.com/watch?v=y3qkf3bajd4.

Bilenky, Serhiy. Romantic Nationalism in Eastern Europe: Russian, Polish, and Ukrainian Political Imaginations. Stanford, CA: Stanford University Press, 2012.

Bilokin, Serhii. Masovyi teror yak zasib derzhavnoho upravlinnia v SRSR (1917-1941 rr.): Dzhereloznavche doslidzhennia [Mass Terror as a Tool of State Governance in the USSR, 1917-1941: A Study of Sources]. Vol. 2. Drohobych: Kolo, 2013.

"Bitva za Stalina [The Battle for Stalin]." Interfax, 2011. Accessed March 28, 2016. http://www. interfax.ru/print.asp?sec=1448\&id=187830.

"Blame for Massacre of Poles Cannot Be Put on Russians - Putin." RT, 2010. Accessed March 28, 2016. https://www.rt.com/politics/katyn-poloes-massacre/.

Brandenberger, David. "A New Short Course?: A. V. Filippov and the Russian State's Search for a 'Usable Past." Kritika: Explorations in Russian and Eurasian History 10.4 (2009): 825-33. 
Brandenberger, David, and Kevin M. F. Platt. "Terribly Pragmatic: Rewriting the History of Ivan IV's Reign, 1937-1956." In Epic Revisionism: Russian History and Literature as Stalinist Propaganda, edited by David Brandenberger and Kevin M. F. Platt, 157-78. Madison: University of Wisconsin Press, 2006.

Brown, Kate. A Biography of No Place: From Ethnic Borderland to Soviet Heartland. Cambridge, MA: Harvard University Press, 2003.

Burds, Jeffrey. "Ethnicity, Memory, and Violence: Reflections on Special Problems in Soviet and East European Archives.” In Archives, Documentation, and Institutions of Social Memory: Essays from the Sawyer Seminar, edited by Francis X. Blouin Jr. and William G. Rosenberg, 466-79. Ann Arbor: University of Michigan Press, 2006.

Cienciala, Anna M., Natalia S. Lebedeva, and Wojciech Materski, eds. Katyn: A Crime Without Punishment. New Haven; London: Yale University Press, 2007.

Danilov, A. A., A. I. Utkin, and A. V. Filippov, eds. Istoriia Rossii, 1945-2008: 11 klass. Uchebnik dlia uchashchikhsia obshcheobrazovatelnykh uchrezhdenii [A History of Russia, 1945-2008: Grade 11. Textbook for Pre-Graduate Students]. Moscow: Prosveshchenie, 2008.

Davies, R.W., Oleg V. Khlevniuk, and E. A. Rees, eds. The Stalin-Kaganovich Correspondence. 193136. Translated by Steven Shabad. New Haven; London: Yale University Press, 2003.

Dawisha, Karen. Putin's Kleptocracy: Who Owns Russia? New York: Simon \& Schuster, 2014.

Doroshko, Mykola. Nomenklatura: Kerivna verkhivka radianskoi Ukrainy (1917-1938 rr.) [Nomenklatura: The Governing Leadership in Soviet Ukraine, 1917-1938]. Kyiv: NikaTsentr, 2008.

Duma, Vasilii. “'Bibliotechnyi skandal' — eto odioznaia politicheskaia provokatsiia [The 'Library Controversy' is an Odious Political Provocation]." Ofitsialnyi sait chlena Soveta Federatsii RF ot Kostromskoi oblasti, 2015. Accessed March 30, 2016. http://www.vduma.ru/article. php?id=316.

Ebon, Martin. KGB: Death and Rebirth. Westport; London: Praeger, 1994.

Etkind, Alexander et al. Remembering Katyn. Cambridge, UK: Polity Press, 2012.

Etkind, Alexander. "The Kremlin's Double Monopoly." In Russia Lost or Found? Patterns and Trajectories, edited by Haski Haukkala and Sinikukka Saari, 186-213. Helsinki: Edita, 2009.

"Federalnyi spisok ekstremistskikh materialov [The Federal List of Extremist Materials]." Ministerstvo Yustitsii Rossiiskoi Federatsii, 2004. Accessed March 28, 2016. http://minjust. $\mathrm{ru} / \mathrm{ru} /$ extremist-materials.

“Federalnyi zakon 'O protivodeistvii ekstremistskoi deiatelnosti' [The Federal Law 'About Countering Extremist Activities']." Sovet bezopasnosti Rossiiskoi Federatsii, 2002. Accessed March 28, 2016. http://www.scrf.gov.ru/documents/17/31.html.

Fedor, Julie. Russia and the Cult of State Security. London; New York: Routledge, 2011.

Felshtinsky, Yuri, and Vladimir Pribylovsky. The Corporation: Russia and the KGB in the Age of President Putin. New York: Encounter Books, 2008.

Filippov, A. V., A. I. Utkin, and S. V. Sergeev, eds. Noveishaia istoriia Rossii, 1945-2006: Kniga dlia uchitelia [A Contemporary History of Russia, 1945-2006: A Teacher's Manual]. Moscow: Prosveshchenie, 2007. 
Fitzpatrick, Sheila. "Introduction: Soviet Union in Retrospect - Ten Years after 1991." In The Legacy of the Soviet Union, edited by Wendy Slater and Andrew Wilson, 1-14. Basingstoke: Palgrave Macmillan 2004.

Forest, Benjamin, and Juliet Johnson. "Unraveling the Threads of History: Soviet-Era Monuments and Post-Soviet National Identity in Moscow." The Annals of the Association of American Geographers, 2001. Accessed March 29, 2016. http://www.dartmouth.edu/ crn/crn papers/Forest-Johnson.pdf.

Garagozov, R.R. "Collective Memory and the Russian 'Schematic Narrative Template." Journal of Russian and East European Psychology 40.5 (2002): 55-89.

Gessen, Masha. The Man Without a Face: The Unlikely Rise of Vladimir Putin. New York: Riverhead Books, 2012.

Gorham, Michael S. After Newspeak: Language Culture and Politics in Russia from Gorbachev to Putin. Ithaca; London: Cornell University Press, 2014.

Illarionov, Andrei. "Putin Was Preparing War for 11 Years." Khartyia'97, 2014. Accessed March 28, 2016. http://www.charter97.org/en/news/2014/11/21/127194/.

"Informatsiia po delam i sudebnym aktam [Information about Cases and Court Protocols]." Meshchanskii raionnyisud goroda Moskvy, 2011. Accessed March 28, 2016. http://meshansky. msk.sudrf.ru/modules.php?name=information\&rid $=45$.

Istoriia Vsesoiuznoi kommunisticheskoi partii (bolshevikov): Kratkii kurs [The History of the AllUnion Communist Party, the Bolsheviks: A Brief Course], edited by the Commission of the Central Committee of the VKP(b). Moscow, 1938.

Jacobsen, Katherine. "Stalin's Story Takes Positive Twist: Tale Turns as Russians Seek Unity." Press Enterprise, March 27, 2016.

Khaustov, Vladimir. Deiatelnost organov gosudarstvennoi bezopasnosti NKVD SSSR (1939-1941 gg.) [The Activities of State Security Organs, the NKVD of the USSR, 1939-1941]. Moscow: Chelovek i nauka, 1998. Accessed March 28, 2016. http://cheloveknauka.com/deyatelnost-organovgosudarstvennoy-bezopasnosti-nkvd-sssr-1939-1941-gg.

Krassa, S.I. "Metody sudebnoi lingvisticheskoi ekspertizy: prakticheskaia tipologiia [The Methods of Juridical Linguistics: A Practical Typology]." Paper delivered at the conference "SWorld: Modern Problems and Ways of their Solution in Science, Transport, Production and Education," December, 18-27, 2012.

Kravchenko, Volodymyr V. "Ukraine Faces its Soviet Past: History versus Policy versus Memory." In Mass Dictatorship and Memory as Ever Present Past, edited by Jie-Hyun Lim, Barbara Walker and Peter Lambert, 87-119. New York: Palgrave Macmillan, 2014.

Kravchenko, Volodymyr. Ukraina, Imperiia, Rosiia: Vybrani statti z modernoi istorii ta istoriohrafii [Ukraine, Empire, Russia: Selected Essays on Modern History and Historiography]. Kyiv: Krytyka, 2011.

Kuzio, Taras. "Ukraine's Security Forces: Bloated, Incompetent and Still Neo-Soviet." Eurasia Daily Monitor, February 6, 2013.

Lovell, Stephen. The Shadow of War: Russia and the USSR, 1941 to the Present. Chichester, West Sussex, UK; Malden, Mass.: Wiley-Blackwell, 2010. 
Lucas, Edward. The New Cold War: Putin's Russia and the Threat to the West. New York: Palgrave Macmillan, 2008.

Lyzanchuk, Vasyl. "Kryvava 'yolka' Yanukovycha [The Bloody Christmas Tree of Yanukovych].” Literaturna Ukraina, December 5, 2013.

Mace, James. "Geopolitical Implications of Ethnopolitics." In The Political Analysis of Postcommunism: Understanding Postcommunist Ukraine, edited by Volodymyr Polokhalo, 301-20. College Station, TX: Texas A\&M University Press, 1997.

Malia, Martin. The Soviet Tragedy: A History of Socialism in Russia, 1917-1991. New York: Free Press, 1994.

Markwick, Roger D. Rewriting History in Soviet Russia: The Politics of Revisionist Historiography, 1956-1974. New York: Palgrave, 2001.

Maslov, Aleksandr, and Aleksei Maslov. Smertelnyi tron: Zagadki poslednikh dnei pravitelei Rossii [The Lethal Throne: The Mysteries of the Last Days of Governors in Russia]. Moscow: Feniks, 2010.

McDermott, Roger. "Putin Approves Draft Strategy for Countering Extremism in Russia to 2025." Eurasia Daily Monitor, November 25, 2014.

Memorial's Official Site. Memorial. Accessed March 28, 2016. http://www.memo.ru/.

Motyl, Alexander J. "Deleting the Holodomor: Ukraine Unmakes Itself." World Affairs, 2010. Accessed March 28, 2016. http://www.worldaffairsjournal.org/article/deleting-holodomorukraine-unmakes-itself.

Motyl, Alexander J. "Putin's Russia as a Fascist Political System." Communist and Post-Communist Studies 49.1 (2016): 25-36.

Norris, Stephen M. Review of Pavel Lungin's Tsar, 2009. Kinokultura 28 (2010). Accessed March 28, 2016. http://www.kinokultura.com/2010/28r-tsar-sn.shtml.

Novodvorskaia, Valeriia, and Konstantin Borovoi. "Statia Putina." YouTube, 2012. Accessed March 30, 2016. http://www.youtube.com/watch?v=05QftBi7HH8.

"Oleg Gazmanov: K Putinu khozhu v futbolke [Oleg Gazmanov: I Visit Putin Wearing a T-Shirt]." Sem40.ru, 2003. Accessed March 29, 2016. http://www.sem4o.ru/famous2/m1866.shtml.

Olsson, John. Forensic Linguistics: An Introduction to Language, Crime and the Law. London and New York: Continuum, 2004.

Olsson, John. "What is the Forensic Linguistics?” The Text, 2015. Accessed March 28, 2016. http:// www.thetext.co.uk/docs/what_is.doc.

"Open Letter to Medvedev." Xindex: The Voice of Free Expression, 2008. Accessed March 28, 2016. http://www.indexoncensorship.org/2008/12/an-open-letter-to-president-medvedev/.

Osipov, Alexander. "Ethnicity, Discrimination and Extremism in Russia." Problems of PostCommunism 57.2 (2010): 50-60.

Pain, Emil A. "Xenophobia and Ethnopolitical Extremism in Post-Soviet Russia: Dynamics and Growth Factors." Nationalities Papers 35.5 (2007): 895-911.

Paneiakh, Ella. "Zachem prokurature 'Memorial'? [Why Does the Prosecutor's Office Need 'Memorial'?]." Polit.ru, 2008. Accessed March 28, 2016. http://www.polit.ru/ article/2008/12/10/memorial1/.

Pauly, Matthew D. Breaking the Tongue: Language, Education, and Power in Soviet Ukraine, 19231934. Toronto: University of Toronto Press, 2014. 
Pomerantsev, Peter. Nothing is True and Everything is Possible: The Surreal Heart of the New Russia. New York: Public Affairs, 2014.

"Populiarnost Stalina sredi rossiian osnovana na emotsiiakh i mifakh [Stalin's Popularity Among Russians Is Based on Emotions and Myths]." NEWS.ru.com, 2003. Accessed March 28, 2016. http://www.newsru.com/world/o5mar2003/stalin3.html.

Plokhy, Serhii. Ukraine and Russia: Representations of the Past. Toronto: University of Toronto Press, 2008.

"Putin Deplores Collapse of USSR." BBC News, 2005. Accessed 29 March 2016. http://news.bbc. co.uk/2/hi/4480745.stm.

"Putin: Rossiia pobedila by v voine i bez Ukrainy [Putin: Russia Would Have Won the War Without Ukraine]." Fokus.UA, 2010. Accessed March 30, 2016. http://focus.ua/politics/161151.

"Russia Regresses." The Boston Herald, republished in Press Enterprise, December 24, 2013.

Salvatici, Silvia, ed. Confini. Costruzioni, attraversamenti, rappresentazioni. Soveria Mannelli, Catanzaro: Rubbettino, 2005.

Sanders, Jonathan. "Foreword." In Victims of Soviet Terror: The Story of the Memorial Movement, edited by Nanci Adler. Westport, Connecticut: Praeger, 1993.

“'Sdelan v SSSR': pesnia Gazmanova vozmutila Pribaltiku [Made in the USSR: Gazmanov's Song Infuriated the Baltics]." Argumenty i fakty, January 4, 2014. Accessed March 30, 2016. http:// www.aif.ru/culture/showbiz/1065724.

Semystiaha, Volodymyr. "The Role and Place of Secret Collaborators in the Informational Activity of the GPU-NKVD in the 1920s and 1930s (on the Basis of Materials of the Donbass Region)." Cahiers du Monde russe 42.2-4 (2001): 231-44.

Shapoval, Yurii. "Rosiiske kerivnytstvo obralo ahresyvnu liniiu shchodo ukrainskykh orhanizatsii [The Russian Leadership Has Chosen an Aggressive Course in Regards to Ukrainian Organizations]." Tyzhden, 2012. Accessed March 28, 2016. http://tyzhden.ua/Politics/57335.

Shapoval, Yurii, Volodymyr Prystaiko, and Vadym Zolotariov. ChK-GPU-NKVD v Ukraini: Osoby, Fakty, Dokumenty [ChK-GPU-NKVD in Ukraine: Individuals, Facts, Documents]. Kyiv: Abris, 1997 .

Sharlet, Robert. "Stalinism and Soviet Legal Culture." In Stalinism: Essays in Historical Interpretation, edited by Robert C. Tucker. New York: W. W. Norton \& Company, Inc., 1977.

Sheiko, Konstantin (in collaboration with Stephen Brown). Nationalist Imaginings of the Russian Past: Anatolii Fomenko and the Rise of Alternative History in the Post-Communist Russia. Stuttgart: Ibidem-Verlag, 20og.

Shevtsova, Lilia. "Political Leadership in Russia's Transformation." In Russia's Engagement with the West: Transformation and Integration in the Twenty-First Century, edited by Alexander J. Motyl, Blair A. Ruble and Lilia Shevtsova, 99-120. New York; London: M. E. Sharpe, 2005.

Shkandrij, Myroslav. Jews in Ukrainian Literature: Representation and Identity. New Haven; London: Yale University Press, 2009.

Shkandrij, Myroslav, and Olga Bertelsen. "The Soviet Regime's National Operations in Ukraine, 1929-1934." Canadian Slavonic Papers LV.3-4 (2013): 417-47.

Shlapentokh, Vladimir. A Normal Totalitarian Society: How the Soviet Union Functioned and How it Collapsed. New York: M. E. Sharpe, 2001. 
Snyder, Timothy. Sketches from a Secret War: A Polish Artist's Mission to Liberate Soviet Ukraine. New Haven; London: Yale University Press, 2005.

Soldatov, Andrei, and Irina Borogan. The New Nobility: The Restoration of Russia's Security State and the Enduring Legacy of the KGB. New York: Public Affairs, 2010.

"Sud priznal zakonnym prodlenie sroka domashnego aresta Natalie Sharinoi [The Court Extended Natalia Sharina's Domestic Arrest].” Memorial, 2016. Accessed March 28, 2016. http://memohrc.org/news/sud-priznal-zakonnym-prodlenie-sroka-domashnego-arestanatale-sharinoy.

Tepliakov, A. G. "Mashina terrora: OGPU-NKVD Sibiri v 1929-1941 gg. [The Machine of Terror: OGPU-NKVD in Siberia, 1929-1941]." Memorial, 2008. Accessed March 28, 2016. http:// www.memorial.krsk.ru/Articles/2008Teplyakov/oo.htm.

Tismăneanu, Vladimir. "Coming To Terms with a Traumatic Past: Reflections on Democracy, Atonement, and Memory." In History in Communism in Europe, edited by Corina Dobos and Marius Stan, 15-20. Villejuit Cedex, FRA: Zeta Books, 2010.

Tumanov, Grigorii. "Biblioteku ukrainskoi literatury v Moskve mogut likvidirovat [The Library of Ukrainian Literature Might be Closed]." Kommersant.ru, 2015. Accessed March 28, 2016. http://kommersant.ru/doc/288295o.

"Ugolovnyi Kodeks RF s komentariiami. Komentarii k statie 282 [The Criminal Code of the Russian Federation with Comments. Comments to the Article 282]." Ugolovnyi Kodeks RF, 1996, 2015 ed. Accessed March 28, 2016. http://rfuk.ru/comment_282.html.

Velikanova, Olga. "Soviet Archives and Dark Truths (Jamie Glazov's Interview)." FrontPage Magazine, 2009. Accessed March 28, 2016. http://archive.frontpagemag.com/readArticle. aspx? ARTID $=33973$.

Vilde, L. I., and M. V. Nechkina. "Dekabrist Mikhail Orlov — kritik 'Istorii' N. M. Karamzina [The Decemberist Mikhail Orlov — a Critic of N. M. Karamzin's 'History']." Literaturnoe nasledstvo 59 (1954): 557-68.

"Visitors of Ukrainian Library in Moscow Wanted by Police." Ukraine Today, April 12, 2016. Accessed May 5, 2016. http://uatoday.tv/politics/visitors-of-ukrainian-library-in-moscowwanted-by-police-629267.html.

Voltskaia, Tatiana. "Krym kak lozung i aria [Crimea as Propaganda and an Aria]." Radio Svoboda, 2014. Accessed March 29, 2016. http://www.svoboda.org/content/article/25452116.html.

Vronska, Tamara. Upokorennia strakhom: Simeine zaruchnytstvo u karalnii praktytsi radianskoi vlady (1917-1953) [Subversion by Fear: Family Members as Hostages in Punitive Practice of Soviet Power, 1917-1953]. Kyiv: Tempora, 2013.

Waller, Michael J. "Putin Celebrates Birth of KGB, USSR's Hated Spy Service." Center for Security Policy, 2013. Accessed March 28, 2016. http://www.centerforsecuritypolicy.org/2013/12/20/ putin-celebrates-birth-of-kgb-ussrs-hated-spy-service.

Waller, Michael J. "Russia: Death and Resurrection of the KGB." Demokratizatsiia 12.3 (2004): 333-55.

Weigle, Marcia A.Russia's Liberal Project: State-Society Relations in the Transition from Communism. University Park: The Pennsylvania State University Press, 2000. 
Yaroshevskii, Aleksei. "Stalin vernulsia v Moskovskoe metro [Stalin Returned to Moscow's Subway]." Russia Today, 2009. Accessed March 28, 2016. http://inosmi.ru/video/ 20090904/252288.html.

Zashkilniak, Leonid. Suchasna svitova istoriohrafiia [Contemporary World Historiography]. Lviv: PAIS, 2007.

Zavortnov, Semen. Kharkovskaia Katyn [Kharkiv's Katyn]. 2nd ed. Kharkiv: Konsum, 2004. Žižek, Slavoj. Violence. New York: Picador, 2008.

\section{证}

Olga Bertelsen received her PhD at the University of Nottingham (UK), and is currently a Postdoctoral Fellow at the Harriman Institute, Columbia University (US). Her research interests include Ukrainian and Russian histories and cultures, state violence and psychiatric terror, authoritarian regimes, Soviet secret police, human behavior under authoritarian rule, national minorities in the Soviet Union, and the state vs. the intelligentsia. Among her most recent publications are the monograph "The House of Writers in Ukraine, the 1930s: Conceived, Lived, Perceived," published in The CarlBeck Papers, and a collection of new archival documents about the persecution of Jews in the Soviet Union in two parts, published in On the Jewish Street. 